\title{
Exploring the Implementation of Business Process Reengineering in Banks
}

\author{
Kabiru Jinjiri Ringim ${ }^{1}$, Nor Hasni Osman ${ }^{1}$, Norlena Hasnan ${ }^{1} \&$ Mohd Rizal Razalli $^{1}$ \\ ${ }^{1}$ College of Business, School of Technology Management and Logistics, Universiti Utara Malaysia, Sintok \\ 06010, Kedah, Malaysia
}

Correspondence: Kabiru Jinjiri Ringim, College of Business, School of Technology Management and Logistics, Universiti Utara Malaysia, Sintok 06010, Kedah, Malaysia. Tel: 60-17-525-2975. E-mail: kabirujinjiri@yahoo.com

Received: June 9, 2013 Accepted: June 26, 2013 Online Published: August 30, 2013

doi:10.5539/ass.v9n11p243

URL: http://dx.doi.org/10.5539/ass.v9n11p243

\begin{abstract}
The changing dynamics of banking and business environment forced banks to re-engineer their operational process for fantastic business performance. The bank operational process which is intended to meet emerging challenges of bank consolidation, operating cost containment, improvement of customer service and increase revenue call for innovative banking practices through Business Process Re-engineering. This is to enable Nigerian banks to incorporate strategic innovative customer schemes in order to bridge the service gap inherent in a Nigerian banking sector. The broad objectives of this study are: 1) to determine the current status of an operational process reengineered in the Nigerian banks; and 2) To determine the most organizational objective of BPR implementation in Nigerian banks. Self- delivery and collection of data strategy with help of research assistants were used to in this study. Out of 560 questionnaires distributed to the sampled banks, 417 were returned representing $74 \%$ rate. First, the study found that Nigerian banks surveyed have re-engineered their branch operations, customer services, cash tellering services, cheque's clearing, domestic fund transfer, loan processing, credit administration and appraisal. In addition, $21.3 \%$ of the banks surveyed have reengineered their services with respect to foreign operations, process for letter of credit, Western Union/MoneyGram money payment and wire transfer to a fund through SWIFT and other electronic channels. Second, the result showed that $24.7 \%$ of the surveyed banks agreed that enhancement of profit is the most objective of BPR implementation. These followed closely by $23.3 \%$ of the surveyed banks that are of the opinion that improvement over the quality of customer service is the most objective of BPR adoption. Furthermore, $20.4 \%, 11.5 \%$ and $12.9 \%$ of the survey banks are of the opinion that organisation objective of BPR adoption was to either be proactive, reactive for future/current challenges, competitive pressure being faced as a result of globalization and deregulation of the financial sector or to reduce operating cost respectively. The outcome from this study provides important insights to both managers and researchers for further understanding about the objectives of BPR adoption, and the operational processes reengineered by the banks. The necessary suggestions on new area of research were recommended for future study.
\end{abstract}

Keywords: business process reengineering (BPR), operational processes, banks, Nigeria

\section{Introduction}

The globalization of the banking services gave rise to the demand for quick service delivery in financial service segment (Randle, 1995). The liberalization of the banking sector and high-technology capability have necessitated the financial service outfits to engage in process reengineering. This brought about revolutionary changes in efficiency and accuracy to meet the customer's requirement. The consequences of liberalisation, deregulation and presence of high-technology capacity in small and medium banks help to streamline the back office operational processes to improve both efficiency and cost reduction (Aregbeyen, 2011). Advances in technology influence the way banks' services are delivered with the aim of making them more convenient for customers. Central Bank of Nigeria (CBN) initiated business process reengineering (BPR) project tagged EAGLES (Efficiency, Accountability, Goal orientations, Leadership, Effectiveness and Staff motivation). The objective is to enhance the operational processes and service quality delivery of banks (CBN, 2009). The CBN in partnership with PricewaterhouseCoopers conducted a comprehensive assessment of the bank's core and non-core operations that 
required fundamental restructuring for internal transformation such as customer service delivery, regulatory function of the $\mathrm{CBN}$, performance management \& benchmarking, information technology (IT), customer satisfaction, human resources and administration and communication effectiveness at all stakeholder levels (CBN, 2009). In doing so, past Management initiatives that have given satisfactory results in manufacturing sector was reengineering of processes. Process reengineering gives attention to a new fashion that resulted to high-performance improvement in terms of all criteria of performance measurement (Goll \& Cordovano, 1993). The focus of process reengineering is on redesigning of the entire processes from old-fashioned to a newer and highly improved approach for remarkable performance achievement (Allen (1994). The 1,023 registered banks (both Commercial, Mortgage and Microfinance) are doing business in volatile environment that is characterised by frequent changes in government policies and steep competition. The liberalization of the banking sector and high-technology capability have forced the small and medium banks to engage in process reengineering. This brought about revolutionary changes in efficiency and accuracy to meet the needs of the customer (Aregbeyen, 2011). IT in a banking sector is an important tool that helped to streamline the back-office operations by improving both efficiency and cost reduction (David-West, 2005). Advances in technology influence the way banks' services are delivered with the aim of making them more convenient for customers. For example, many banks in Nigeria have their branches connected online real time (24/7). Some banks have ATMs to make cash available to their customers 24/7. Nigerian bank's practice e-banking, telephone, and mobile services, Money transfer services through MoneyGramme, and Western Union Money transfer. These enabled the Nigerian in Diaspora to send money to their families (CBN, 2008). Moreover, the IT capability (IT operations and IT knowledge) makes Nigerian banks participate more effectively in the financial service arena. For instance, some organization can access international banking networks for efficient fund transfers, open, amend, and negotiate letters of credit, and retrieve up-to-date status of customer transactions between the banks that joined the Society for Worldwide Inter-bank Financial Telecommunication (SWIFT) (Ringim, Razalli, \& Hasnan, 2011).

However, Herzog, Polajnar, \& Tonchia, (2007) argued that BPR studies can be divided to two groups of scholars, i.e. the authors that agreed-on BPR as a solution to the dynamic and volatile business environment, that is characterised by frequent market changes, customer demand and competition and 2) the scholars who are of the view that BPR failed to achieve the desired expectation. Multi-National Companies operating in Europe and USA had a remarkable breakthrough by adoption of business process reengineering (Al-Mashari, Irani \& Zairi, 2001). Hence, the expectation to achieve a radical performance measure was not met. In addition, scholars argue that majority of studies on BPR focused on the manufacturing industry. Only few BPR studies to the knowledge of the researcher have done BPR study at the financial service sector such as a bank. Moreover, there was a dearth in BPR literature with a thorough procedural approach on BPR as argued by some researchers such as Motwani et al., (1998); Al-Mashari et al., (2001) and Tenant \& Wu, (2005). Hence, this study was conducted in a banking sector to bridge the gap on a theoretical and conceptual discussion. The purpose of this paper is: 1) To determine the current status of an operational process reengineered in the banks; and 2) To determine the organizational objective of BPR adoption in Nigerian banks.

\section{Literature Review}

The concept of reengineering or process redesign was popularised by scholars such as Hammer and Champy, 1993, who refers BPR as a process redesigns using technology to achieve a performance increase in cost reduction, quality services and profit measured in geometrical progression. BPR is a complete process transformation, radical in nature that discourages bureaucratic structure in organisation to core process specialisation (Al-Mashari \& Zairi, 2000; Siha \& Saad, 2008; Ozcelik, 2010). Process reengineering broke down activities into processes instead of structures to achieve organisation desired objectives (Cheng, Tsai \& Xiano, 2006). Adoption of BPR in an organization would enable it gains some benefits in that would sky rocketed their performance in business (Shin \& Jemella, 2002). BPR assisted organisations in both manufacturing and financial services to over-come the process in-efficiency and operational performance. Herzog, Polajnar \& Tonchia, (2007) defined business process reengineering as a management discipline for analyzing and redesigning current business processes and their components in terms of efficiency, effectiveness and added value to the objectives of the business. The conduct of the BPR steps is planned to gather and process business requirements in support of a modernization effort for a defined area. The BPR starts with planning activities that include the creation of a BPR team, the development of a BPR scope document and an examination of the proposal that relates to a given area, examines the existing and future business process and improves it accordingly. The successful implementation of BPR depends on how the project fits within the organization cultural norms, and IT (Ahmad, Francis, \& Zairi, 2007; Al-Mashari \& Zairi, 1999; Attaran, 2004; Bhatt, 2000; Davenport \& Short, 1990; Hammer \& Champy, 1993; Khong \& Richardson, 2003; Murray \& Lynn, 1997). 
Reengineering is the fundamental rethinking and radical redesign of business processes to achieve dramatic improvements in a critical quantum leap of contemporary measures of performance, such as cost, quality, service, and speed (Hammer \& Champy, 1993). This definition comprises four keywords: fundamental, radical, dramatic improvement and processes. BPR seeks to split away from the old and current processes to come up with an improved procedure and channel of activities in new fashion that enable use of IT with support of people in organisation. The basic operation of a business is the first and important priority to reengineering. The essential question of how an organization should be run should be asked by the business owners; the answers for these questions always lead to an understanding of the fundamental operations within the company and rationale behind any existing assumption. Re-engineering starts with no assumption and companies that implement reengineering must guard against such assumptions, take nothing for granted and must determine what a company needs and how effectively it can be done. Radical redesigning is the second keyword to reengineering, which means abandoning all existing arrangement and methods and creating a completely new contemporary system of achieving a task. This means that reengineering is all about beginning with a new process with no assumption or modification. Therefore, business processes are re-innovated. The third keyword in the BPR concept is dramatic improvement, reengineering, which involves achieving greater performance unlike making incremental improvement. Marginal improvement requires re-adjustment while dramatic improvement demands doing away with an existing process and replacing it with something new and contemporary. The fourth keyword in defining BPR is processes. This is the paramount concept in reengineering. The division of labour approach, which is wholly applied in classic business structure, should be transformed to the process-based approach to ensure the effectiveness and efficiency of processes.

\section{Methodology}

The study was descriptive conducted to understanding of the banks objective about BPR implementation and to provide a more specific description of the percentages of the operational processes reengineered by the banks (Zikmund, 2000; Sekaran, 2003). The unit of analysis for this study is organisation with population of 1,023 banks (consisting of 24 commercial banks, 901 microfinance bank and 98 primary mortgage finance). Sample size of 285 Organisations was used in this study. Hence a sample size of 285 was arrived after the formulae computation (Dillman, 2000; Weaver, 2006). Stratified random probability sampling technique was used to draw a sample from each stratum proportionate to the total number of element in the respective strata. 560 questionnaires were distributed among the 1,023 banks with aim to achieve at least $50 \%$ response rate of 280 in order to ensure that non-response bias and non-response rate did not affect the results for this study (Ringim et al., 2012; Phokhwang, 2008). Hand delivery with help of research assistant strategy for data collection was adapted for efficiency in environment where research culture is not sufficiently developed (Asika, 1991). The adapted questionnaire from a previous study conducted on BPR implementation (Al-Mashari \& Zairi, 1999; Cheng \& Chiu, 2008) measures the influence on the research independent variable BPR factor was used for the study. To ensure effective adaptation of the instrument, proper validation of the questionnaire items was done by the researcher. A six-point Likert scale rating was used in order to prevent the respondents from marking easy choice. Prior to the main study, a pilot test was conducted to get feedback on the measurement instrument for adjustment and smooth flow for data collection, the questionnaire and the techniques used in analyzing data, and pre-test results were explained in the following paragraphs.

\subsection{Construct Validity and Reliability Test}

The reliability of all the items was examined through the Cronbach's Alpha, factor loadings and the index of composite reliability (see Table 1). Although, there is a lot of debate concerning the best method to estimate reliability, coefficient alpha remains the commonly used method even though it may underestimate reliability (Hair et al., 2010). The different methods of assessing reliability produced similar results. The values of Cronbach's alpha and composite reliability are shown in the appendix Table 1. Fornell and Larcker, (1981) argued that composite reliability is more robust than Cronbach's alpha. From the table, it is obvious that each of the indexes of construct reliability (composite reliability) is greater than the threshold of .7 (Fornell \& Larcker, 1981). The composite reliability values range between .7307 and .9803 . This result means that the constructs have internal consistency, and that all the measures consistently represent the same latent construct. Although, composite reliability is stronger than the Cronbach's alpha, in this study, the latter was also assessed in order to complement the former. Table 1 presents factor loadings for all the items ranging from .544 to .984 , confirming that the indicators are strongly related to their various constructs. Hence, it indicates to well construct validity (Hair et al., 2010). 
Table 1. Construct's validity and reliability

\begin{tabular}{|c|c|c|c|c|c|c|}
\hline Constructs & $\begin{array}{l}\text { Item } \\
\mathrm{s}\end{array}$ & $\begin{array}{l}\text { Factor } \\
\text { Loadings }\end{array}$ & $\begin{array}{l}\text { Average } \\
\text { Extracted }\end{array}$ & Variance & $\begin{array}{l}\text { Composite } \\
\text { Reliability }\end{array}$ & $\begin{array}{l}\text { Cronbach' } \\
\text { s Alpha }\end{array}$ \\
\hline \multirow[t]{4}{*}{ IT Investment } & E3 & .773 & \multirow[t]{4}{*}{.501} & & \multirow[t]{4}{*}{.796} & \multirow[t]{4}{*}{.751} \\
\hline & E4 & .755 & & & & \\
\hline & F2 & .722 & & & & \\
\hline & E2 & .551 & & & & \\
\hline \multirow[t]{5}{*}{ BPR Strategy } & B1 & .754 & \multirow[t]{5}{*}{.534} & & \multirow[t]{5}{*}{.821} & \multirow[t]{5}{*}{.730} \\
\hline & B4 & .740 & & & & \\
\hline & B3 & .718 & & & & \\
\hline & B2 & .710 & & & & \\
\hline & D4 & .740 & & & & \\
\hline \multirow{3}{*}{ Customer Focus } & D3 & .735 & \multirow{3}{*}{.539} & & \multirow[t]{4}{*}{.824} & \multirow{4}{*}{.738} \\
\hline & D1 & .734 & & & & \\
\hline & $\mathrm{D} 2$ & .728 & & & & \\
\hline \multirow{4}{*}{$\begin{array}{l}\text { Management } \\
\text { Commitment }\end{array}$} & $\mathrm{C} 7$ & .792 & \multirow{4}{*}{.560} & & & \\
\hline & C6 & .772 & & & \multirow[t]{3}{*}{.792} & \multirow[t]{3}{*}{.712} \\
\hline & $\mathrm{C} 5$ & .676 & & & & \\
\hline & A8 & .749 & & & & \\
\hline \multirow[t]{2}{*}{ Communication } & A2 & .719 & \multirow[t]{2}{*}{.525} & & \multirow[t]{2}{*}{.768} & \multirow[t]{2}{*}{.715} \\
\hline & A5 & .705 & & & & \\
\hline Training \& & A3 & .767 & & & & \\
\hline \multirow[t]{3}{*}{ Education } & A9 & .728 & \multirow[t]{3}{*}{.508} & & \multirow[t]{3}{*}{.755} & \multirow[t]{3}{*}{.706} \\
\hline & A7 & .638 & & & & \\
\hline & G5 & .761 & & & & \\
\hline Volume of financial & G4 & .713 & .546 & & .760 & .683 \\
\hline Activities. & F5 & .633 & & & & \\
\hline & $\mathrm{F} 4$ & .544 & & & & \\
\hline Rewards & A4 & .974 & 947 & & 973 & 976 \\
\hline Kewards & A1 & .972 & . 941 & & . 913 & .910 \\
\hline Strong Canital base & G2 & .783 & 577 & & 732 & 600 \\
\hline & G1 & .736 & & & & \\
\hline & A1 & .972 & & & & \\
\hline & A2 & .719 & & & & \\
\hline & A3 & .767 & & & & \\
\hline Change & A4 & .974 & 638 & & 030 & 771 \\
\hline Management. & A5 & .705 & . & & (2) & $.1 / 1$ \\
\hline & A7 & .638 & & & & \\
\hline & A8 & .749 & & & & \\
\hline & A9 & .728 & & & & \\
\hline & GI & .736 & & & & \\
\hline & G2 & .783 & & & & \\
\hline Financial Resources & G4 & .713 & 500 & & 850 & 706 \\
\hline 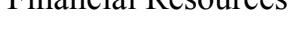 & G5 & .761 & .030 & & . 030 & .100 \\
\hline & F4 & .544 & & & & \\
\hline & F5 & .633 & & & & \\
\hline
\end{tabular}


The purpose of analysing the validity of an instrument was to ensure that items measure correct as prescribed and fully explained (Zikmund (2000). Management scholars and researchers use statistical techniques to assess discriminant validity using average variance extraction (AVE) methods (Fornell \& Larcker, 1981). Table 2 in the appendix clearly indicates all the square roots of AVE ranging between 0.731 and 0.981 are greater than the values of the constructs in the corresponding matrices. This indicates that each constructs shares more variance with its items than with other constructs, and supports discriminant validity.

Table 2. Discriminant validity

\begin{tabular}{lllllll}
\hline & 1 & 2 & 3 & 4 & 5 & 6 \\
\hline 1. I.T Investment. & .773 & & & & & \\
2. BPR Strategic Alignment & .067 & .731 & & & & \\
3. Customer Focus & .108 & .254 & .734 & & & \\
4. Management Commitment & .403 & .184 & .084 & .748 & & \\
5. Change Management & .072 & .182 & .123 & .049 & .799 & \\
6. Adequate Financial Resources. & .494 & .125 & .074 & .429 & .086 & .768 \\
\hline
\end{tabular}

Note. The value in the diagonal is square root of AVE

\section{Statistical Analysis and Discussions}

\subsection{Respondent and Organizational Background}

The presentation of the original data sets in the form of frequency Tables 3 to 5 , as well as the analytical Tables 6 to 7 are in the appendix. The officers who participated on behalf of their organisations were head of Departments and Managers on higher-grade levels. The questionnaire was answered from both Commercial, Mortgage and Microfinance banks respectively. At the end of data cleaning exercises only 74.8 percent of 417 became useable for further data analysis. Out of 417 , responses received from the banks, $75 \%$ of them fall within a category of organization (Microfinance bank and Primary Mortgage bank) without ATM machines, POS, etc. Only $14 \%$ of banks have a network of 99 branches with ATM Machines; $5.0 \%$ of the participating banks have a network of 300 to 499 branches with ATM machines, and 4\% of banks involved in the survey have a network of 100 to 299 branches that have ATM machines installed onsite. As for the location of branches, $47 \%$ of the respondents indicated that most of their bank branches are located within the commercial and state capital, $21 \%$ were sited in-state capitals and a few in cities, and 13\% were located in urban and rural areas with a few branches in cities.

Table 3. Job title

\begin{tabular}{lllll}
\hline & Frequency & Percent & Valid Percent & Cumulative Percent \\
\hline ED/GM & 65 & 15.6 & 15.6 & 15.6 \\
DGM/AGM & 82 & 19.7 & 19.7 & 35.3 \\
SM/MGR & 125 & 30.0 & 30.0 & 65.2 \\
HOD & 145 & 34.8 & 34.8 & 100.0 \\
Total & 417 & 100.0 & 100.0 & \\
\hline
\end{tabular}

Table 4. Category of bank

\begin{tabular}{lllll}
\hline & Frequency & Percent & Valid Percent & Cumulative Percent \\
\hline Commercial bank & 18 & 4.3 & 4.3 & 4.3 \\
Microfinance bank & 312 & 74.8 & 74.8 & 79.1 \\
Primary Mortgage & 87 & 20.9 & 20.9 & 100.0 \\
Total & 417 & 100.0 & 100.0 & \\
\hline
\end{tabular}


Table 5. Number of branches with ATM machines

\begin{tabular}{|c|c|c|c|}
\hline Frequency & Percent & Valid Percent & Cumulative Percen \\
\hline $\begin{array}{l}1000 \text { to } 500 \text { number of branches with ATM7 } \\
\text { Machines }\end{array}$ & 1.7 & 1.7 & 1.7 \\
\hline $\begin{array}{l}499 \text { to } 300 \text { number of branches with ATM21 } \\
\text { Machines }\end{array}$ & 5.0 & 5.0 & 6.7 \\
\hline $\begin{array}{l}299 \text { to } 100 \text { number of branches with ATM16 } \\
\text { Machines }\end{array}$ & 3.8 & 3.8 & 10.6 \\
\hline $\begin{array}{l}99 \text { to } 01 \text { number of branches with ATM59 } \\
\text { Machines }\end{array}$ & 14.1 & 14.1 & 24.7 \\
\hline $\begin{array}{l}\text { Other category of orgn without ATM } 314 \\
\text { Machines, POS, etc }\end{array}$ & 75.3 & 75.3 & 100.0 \\
\hline Total & 100.0 & 100.0 & \\
\hline
\end{tabular}

Table 6. Operational process reengineered in Nigerian banks

\begin{tabular}{lllll}
\hline S/N & Operational Processes & Frequency Percent & Cumulative Percent \\
\hline 1 & ONLY Branch OPS - CSO, TELLERING, CLG, 49 & 11.8 & 11.8 \\
& FTO & & \\
2 & Only e-banking services - ATM, POS, INTERNET, 6 & 1.4 & 13.2 \\
3 & MOBILE, T/PHONE & & & 19.4 \\
3 & Only Loan processing, Credit admin and appraisal & 26 & 6.2 & 19.4 \\
4 & Only INTOPS - L/C, FX,Western 2 & .5 & 19.9 \\
5 & Union/MoneyGram, SWIFT & 239 & 57.3 & 77.2 \\
5 & ONLY 1\&3 PROCESSES & 5 & 1.2 & 78.4 \\
6 & ONLY 1,2 \& 3 PROCESSES & 1 & .2 & 78.7 \\
7 & ONLY 1,3 \& 5 PROCESSES & 89 & 21.3 & 100.0 \\
8 & ALL 1,2,3,4, 5 \& 6 PROCESSES & 417 & 100.0 & \\
& Total & & & \\
\hline
\end{tabular}

Table 7. Most objectives of BPR to organization

\begin{tabular}{lllll}
\hline S/N & Objectives & Frequency & Percent & $\begin{array}{l}\text { Cumulative } \\
\text { Percent }\end{array}$ \\
\hline 1 & Increasing revenue & 103 & 24.7 & 24.7 \\
2 & Improving the quality of customer service & 97 & 23.3 & 48.0 \\
3 & Reactive approach to competitive pressure & 48 & 11.5 & 59.5 \\
4 & Reducing operating cost & 54 & 12.9 & 72.4 \\
5 & Proactive approach for future challenges & 85 & 20.4 & 92.8 \\
6 & To achieve obj 1,2,3, \& 4 & 7 & 1.7 & 94.5 \\
7 & To achieve obj 1,2, 4 \& 5 & 23 & 5.5 & 100.0 \\
& Total & 417 & 100.0 & \\
\hline
\end{tabular}

\subsection{Operational Process Reengineered in Banks}

Table 6 show the summary of operational processes reengineered in Nigerian banks. It demonstrated 239 out of 417 banks (both Commercial, Mortgage and Microfinance) represents $57.3 \%$ of the banks surveyed have re-engineered their branch operations, customer services, cash tellering services, cheque's clearing, domestic fund transfer, loan processing, credit administration and appraisal. This followed by 89 banks, i.e. $21.3 \%$ of the Commercial, Mortgage and Microfinance banks that participated in the survey that in addition to reengineering of the domestic and loan operational process, they have reengineered their services with respect to foreign operations, process for letter of credit, Western Union/MoneyGram money payment and wire transfer to a fund through SWIFT. The banks introduced e-cards services such as debit cards, credit card, ATM cards, Internate 
banking, and mobile banking and merchant POS transactions. However, 49 banks, i.e. $11.8 \%$ of the surveyed Commercial, Mortgage and Microfinance banks claimed to have only reengineered their branches operational processes that include customer services, fund transfer and cashiering/tellering only. Only twenty six (26) organizations represent $6.2 \%$ of the surveyed respondents who have only re-engineered their loan processing, credit administration and appraisal. Therefore, the reengineering processes in banks involved redesigning of core processes and re-evaluation of domestic and foreign services that included some aspect of innovation.

\subsection{Most Objectives of BPR Implementation to Organization}

Table 7 indicated that increasing revenue inform of profit margin performance is the most objectives of BPR implementation to Nigerian banks (both Commercial, Mortgage and Microfinance). The enhancement of profit objective has accounted $24.7 \%$ representing 103 banks opinions that participated in the survey. Nigerian banks were confident that the concept of Reengineering is a "fundamental rethinking and radical redesign of business processes to achieve dramatic improvements in a critical quantum leap of contemporary measures of performance, such as cost, quality, service, and speed" (Hammer \& Champy, 1993). The history of the Nigeria banking system is complete with growth and burst cycles of outlets. The total asset of all the banks operating in Nigeria increased within a year after consolidation. An assessment of the level of capitalization, intermediation activities improved significantly and the leverage ratio decline (CBN, 2008; Somoye, 2008). Thus, the consolidation has improved the structure of banks in terms of asset size, deposit base and capital adequacy.

Similarly, 23.3\% represent 97 organizations opinion that the most objective of BPR implementation by those organizations is to improve the quality of customer service. The achievement of the objective is in consonance with argument on liberalization of banking sector and the revolutionary changes in efficiency and accuracy to customer needs through effective relationship management (Aregbeyen, 2011). In addition, technological advancement as a result of globalization greatly influenced the banks objective about reengineering their process in order to deliver a more convenient and personalize service to their customers. The globalization and deregulation gave emergence of new-generation banks with technological capabilities such as Internate and ebanking services have revolutionized the Nigerian banking sector (Agboola, 2008). Different ebanking channels of services such as Internate banking, mobile banking, and ATM card transactions were introduced (Agboola, 2008). The development of online banking services offers opportunities for the banks to be retained, and expanded customer base enjoys customer's loyalty for convenient shopping, enhanced competitive advantage reduce the number of branches and right size the operational staff (Agboola, 2007).

Furthermore, 85 banks out of 417 that participated in the survey are of the opinion that their organization most objectives of BPR adoption were a proactive approach for future challenges. To endure operating business in un-certainty environment would be a major issue for the Nigerian banking industry. Nigerian banks are operating in a turbulent business environment that faces a lot of challenges as a result of globalization, liberalization of banking sector, competition and technological capability. Whereas, forty eight (48) respondents, i.e. 11.5\% agreed that organization's most objectives of BPR adoption were reactive approaches to the pressure being faced as a result of completion, and deregulation of the financial sector.

Moreover, fifty four (54) Organisations, i.e. 12.9\% of the respondents are of the opinion that their Organisation's most objective about BPR implementation was to reduce operating cost which in turn will increase profit performance. The operating cost for Nigerian banks is driven by a combination of factors, such as the state of infrastructure in the economy; the level of inflation on the economy, insufficient skilled and competent human capital, adoption of new modern technologies for banking operations and insecurity across the country. The effect of the increasing cost of doing business in Nigerian banks is high (Ogubunka, 2010). Ogubunka (2010) reported that a cost trend in the Nigerian financial service sector is a reflection of the cost pressure on the economy. He argued that it is evident bank costs were essentially on a growth path signifying banks must have operated under cost pressure. The bank's operating cost rose by an average of 37.6\% between 2004 and 2008 . Noteworthy, under operating cost, is the quantum rise of $142 \%$ in 2007, as against a decline of $9 \%$ in 2006 . Therefore, for Nigerian banks to operate efficiently, costs must be minimal. It is necessary to manage the costs to the economy to reduce its obvious pressure in the cost trend. Reduced-cost pressure from the banking industry will moderate lending rates and operating cost to produce salutary effects on the economy as a whole (Ogubunka, 2010).

\section{Implication of the Study}

Managers are encouraged to invest in terms of time, money, commitment and other resources to implement the BPR strategies. Evidence from this study suggests that organizations should develop IT support in order to further benefit from various strategic activities. 


\section{Limitation}

The issue of common method variance as argued by Podsakoff et al., (2003) could have been a concern for this study. However, the researcher adopts Harman's (1967) single factor analysis to test the common method bias and the design approach to instrument development to reduce common method bias.

Second, limitation to this study is the collection of data at a point in time being cross-sectional survey research design.

Only one questionnaire was administered in one organisation, hence the response could have been an influence by person being bias on the subject matter.

Fourth limitation on this study is that, the data was collected from only Nigerian banks; hence, the result of this survey may not be applicable to other organisation operating in different environment.

\section{Conclusion}

This paper determines the level of BPR adoption by examining the reengineered operational processes in banks and the most objective of BPR implementation to organization in Nigeria. From the statistical analysis, it was clearly shown that not all Managers in Nigerian banks are aware of the benefit of BPR adoption to enhance organizational performance. $57.3 \%$ of the banks surveyed have re-engineered their branch operations, customer services, cash teller services, cheque's clearing, domestic fund transfer, loan processing, credit administration and appraisal. This followed by 89 banks, i.e. $21.3 \%$ that in addition to reengineering of the branch operations, domestic and loan process, they have reengineered their services with respect to foreign operations, process for letter of credit, Western Union/MoneyGram money payment and wire transfer to a fund through SWIFT. Hence, the reengineering processes in banks involved redesigning of core processes of the domestic and Foreign Service's innovation. Second, the result showed that enhancement of profit is the most objective of BPR implementation by Nigerian banks. These Organisations have accounted 24.7\% representing 103 banks opinions that participated in the survey. Similarly, $23.3 \%$ of the banks surveyed are of the opinion that 97 Nigerian bank's objectives for implementation of BPR were to improve the quality of customer service. Furthermore, 85 banks are of the opinion that their most objective of BPR adoption was too proactive for future challenges. Whereas, forty eight (48) respondents, i.e. 11.5\% agreed that organization's most objectives of BPR adoption were reactive to the pressure being faced as a result of globalization, and deregulation of the financial sector. Moreover, fifty four (54) Organisations, i.e. $12.9 \%$ of the organisation that answered the questionnaire agreed that the most objective of BPR implementation was to reduce operating cost which in turn will increase profit performance. Therefore, It can be concluded that Nigerian bank objective about implementation of BPR was in agreement with conceptual goals of the BPR as popularised by Hammer \& Champy, (1993) and Davenport \& Short, (1990).

\section{References}

Agboola, A. (2007). Information and communication technology (ICT) in banking operations in Nigeria - An evaluation of recent experiences. African Journal of Public Administration and Management, XVIII(1), $1-102$.

Agboola, A. A. (2008). Optimizing the Use of Information and Communication Technology (ICT) in Nigerian Banks. Journal of Internet Banking and Commerce, 13(1), 1-16.

Ahmad, H., Francis, A., \& Zairi, M. (2007). Business process reengineering: critical success factors in higher education. Business Process Management Journal, 13(3), 451-467. http://dx.doi.org/10.1108/14637150710752344

Allen, P. H. (1994). Making consolidation work. The Bankers Magazine, 177, 32-37.

Al-Mashari, M., \& Zairi, M. (1999). Business process reengineering implementation processes: an analysis of key success and failure factors. Business Process Management Journal, 5(1), 87-112. http://dx.doi.org/10.1108/14637159910249108

Al-Mashari, M., \& Zairi, M. (2000). Revisiting BPR: A holistic review of practice and development. Business Process Management Journal, 6(1), 10-42. http://dx.doi.org/10.1108/14637150010283045

Al-Mashari, M., Irani, Z., \& Zairi, M. (2001). Business process reengineering: A survey of international $\begin{array}{lllll}\text { experience. Business Process Management Journal, } & \text { 7(5), }\end{array}$ http://dx.doi.org/10.1108/14637150110406812 
Aregbeyen, O. (2011). Business Reengineering and Organizational Performance in Nigeria: A Case Study of First Bank Nigeria Plc. International Business Management, 5(3), 151-158. http://dx.doi.org/10.3923/ibm.2011.151.158

Asika, N. (1991). Research methodology in the behavioural sciences. Lagos: Longman Nigeria Plc, Nigeria.

Attaran, M. (2004). Exploring the relationship between information technology and business process reengineering. Information \& Management Journal, 41(5), 585-596. http://dx.doi.org/10.1016/S0378-7206(03)00098-3

Bhatt, G. D. (2000). Exploring the relationship between information technology infrastructure and business processes reengineering. Business Management Journal, 6(2), 139-163.

Biazzo, S. (2002). Process mapping techniques and organization analysis: lessons from sociotechnical system theory. Business Process Management Journal, 8(1), 42-52. http://dx.doi.org/10.1108/14637150210418629

CBN. (2008). Central Bank of Nigeria Annual Report and Account as at 31st December. Abuja: Central Bank of Nigeria.

CBN. (2009). Central Bank of Nigeria Annual Report and Account as at 31st December. Abuja: Central Bank of Nigeria.

Cheng, T., \& Chiu, I. (2008). Critical Success Factors of Business Process Re-engineering in the Banking Industry. Knowledge and Process Management, 15(4), 258-269. http://dx.doi.org/10.1002/kpm.316

Davenport, H. T., \& Short, J. E. (1990). The New Industrial Engineering: Information Technology and Business Process Redesign. Sloan Management Review, 11-26.

Davenport, T. (1993). Process Innovation: Reengineering Work through Information Technology. Harvard Business School Press.

David-west, O. (2005). Information technology (IT) integration in banks' consolidation. Zenith Bank Economics Quarterly, 3, 1-61.

Dillman, D. A. (2000). Mail and Internet surveys: The tailored design method (2nd ed.). New York: John Wiley and sons.

Flynn, B., Schroeder, R., \& Sakakibara, S. (1994). Aframework for quality management research and an associated measurement instrument. Journal of Operations Management, 11, 339-366. http://dx.doi.org/10.1016/S0272-6963(97)90004-8

Folan, P., \& Browne, J. (2005). A review of performance measurement: towards performance management. Computers in Industry, 56, 663-680. http://dx.doi.org/10.1016/j.compind.2005.03.001

Fornell, C., \& Larcker, D. F. (1981). Evaluating structural equation models with Unobservable variables and measurement error. Journal of Marketing Research, 18(1), 39-50. http://dx.doi.org/10.2307/3151312

Foss, N. J. (1998). The resource based perspective: An assessment and diagnosis of problems.

Fowler, S. W., Wilcox King, A., Marsh, S. W., \& Victor, B. (2000). Beyond products: new strategic imperatives for developing competencies in dynamic environments. Journal of Engineering and Technology Management, 17(3-4), 357-377. http://dx.doi.org/10.1016/S0923-4748(00)00029-1

Frazier, P. A., Barron, K. E., \& Tix, A. (2004). Testing Moderator and Mediator Effects in Counselling Psychology Research. Journal of Counselling Psychology, 51(1), 115-134. http://dx.doi.org/10.1037/0022-0167.51.1.115

Freeman, E. R. (1984). Strategic Management-A Stakeholder Approach. London: Pitman.

Frieder, L., \& Gregory, W. T. (1996). Bank valuations: Meeting customer and investor need. The Bankers, 179, 49-54.

Ganesh, D. B., \& Ali, F. E. (2010). An empirical examination of the relationship between information technology (IT) infrastructure, customer focus, and business advantages. Journal of Systems and Information Technology, 12(1), 4-16. http://dx.doi.org/10.1108/13287261011032625

Garland, R. (1991). The midpoint on a rating scale: Is it desirable? Marketing Bulletin, 66-70.

Gatian, A. W., Brown, R. M., \& Hicks, J. O. J. (1995). Organizational innovativeness, competitive strategy and investment success. Journal of Strategic Information Systems, 4(1), 43-59. http://dx.doi.org/10.1016/0963-8687(95)80014-H 
Gianni, P. J., \& Grupe, F. H. (1997). Reengineering through simulation modelling. Information Systems Management, 14(3), 61-67. http://dx.doi.org/10.1080/10580539708907061

Gill, T. G. (1995). High-tech hidebound: case studies of information technologies that inhibited organizational learning. Accounting, Management and Information Technologies, 5, 41-60. http://dx.doi.org/10.1016/0959-8022(95)90013-6

Goll, E. O., \& Cordovano, M. F. (1993). Construction time again. CIO, 7, 32-36.

Hair, J., Black, W. C., Babin, B. J., \& Anderson, R. E. (2010). Multivariate data analysis (7th ed.). Uppersaddle River, New Jersey: Pearson Education International.

Hammer, M. (1990). Re-engineering work: Don't automate; obliterate. Harvard Business Review, 68, 104-112.

Hammer, M., \& Champy, J. (1993). Reengineering the Corporation (1st ed.). USA: Harper Collins Inc.

Harman, H. H. (1967). Modern Factor Analysis. University of Chicago Press: Chicago

Herzog, N., Polajnar, A., \& Tonchia, S. (2007). Development and validation of business process reengineering (BPR) variables; a survey research in Slovenian companies. International Journal of Production Research, 45(24), 5811-5834. http://dx.doi.org/10.1080/00207540600854992

Khong, K. W., \& Richardson, S. (2003). Business process reengineering in Malaysian banks and finance companies. Managing Service Quality, 13(1), 54-71. http://dx.doi.org/10.1108/09604520310456717

Motwani, J., Kumar, A., Jiang, J., \& Youssef, M. (1998). Business process reengineering, a theoretical framework and an integrated model. International Journal of Operation and Production Management, 18(9-10), 964-977. http://dx.doi.org/10.1108/EUM0000000004536

Mumford, E. (1995). Creative chaos or constructive change business reengineering versus socio-technical design. In G. Burke, \& J. Peppard (Eds.). Examining Business process reengineering: current perspectives and research directions, 192-216. Kogan.

Murray, M. A., \& Lynn, M. P. (1997). Business process re-engineering/information system development to improve customer service quality. Business Process Management, 3(1), 9-16. http://dx.doi.org/10.1108/14637159710161558

Ogubunka, U. M. (2010). Analytical Review of cost trend in the Nigerian banking industry. The Nigerian Banker. Journal of the Institute of Bankers of Nigeria, 1-18.

Ozcelik, Y. (2010). Do business process reengineering projects payoff: Evidence from the United States. International Journal of Project Management, 28, 7-13. http://dx.doi.org/10.1016/j.ijproman.2009.03.004

Phonkhwang, W. J. (2008). Information needs and uses of Thai Nursing. Unpublished PhD, University of North Carolina., North Carolina.

Podsakoff, P. M., \& Organ, D. W. (1986). Self-reports in organisational research: Problems and prospects. Journal of Management, 12(4), 531-544. http://dx.doi.org/10.1177/014920638601200408

Randle, W. M. (1995). Delivering the future: Redefining the role of banks in new competitive environment. Bank Management, 71(1), 45-58.

Ranganathan, C., \& Dhaliwal, J. S. (2001). A survey of business process reengineering practices in Singapore. Information and Management, 39(2), 125-134. http://dx.doi.org/10.1016/S0378-7206(01)00087-8

Ringim, K. J., Razalli, M. R., \& Hasnan, N. (2011). Effect of Business Process Reengineering Factors on Organizational Performance of Nigerian banks: Information Technology Capability as the Moderating Factor. International Journal of Business and Social Science, 2(13), 198-201.

Ringim, K. J., Razalli, M. R., \& Hasnan, N. (2012). A framework of business process reengineering factors and organisational performance of Nigerian banks. Asian Social Science, 8(4), 203-216. http://dx.doi.org/10.5539/ass.v8n4p203

Ringim, K. J., Razalli, M. R., \& Hasnan, N. (2012). Critical success factors for business process management for small and medium banks in Nigeria. Business and Management Review, 2(1), 83-91. Retrieved from http://www.businessjournalz.org/bmr

Shin, N., \& Jemella, D. F. (2002). Business process reengineering and performance improvement: The case of Chase Manhattan Bank. Business Process Management Journal, 8(4), 1463-7154. http://dx.doi.org/10.1108/14637150210435008 
Siha, S. M., \& Saad, G. H. (2008). Business process improvement: empirical assessment and extensions. Business Process Management Journal, 14(6), 778-802. http://dx.doi.org/10.1108/14637150810915973

Tennat, C., \& Wu, Y. (2005). The application of Business process reengineering in the UK. The TQM Magazine, 17, 537-545. http://dx.doi.org/10.1108/09544780510627633

Terziovski, M., Fitzpatrick, P., \& O'Neill, P. (2003). Successful predictors of business process reengineering (BPR) in financial services. International Journal of Production Economics, 84(1), 35-50. http://dx.doi.org/10.1016/S0925-5273(02)00378-X

Weaver, M. (2006). Formulae for calculating sample size, a statistics consultant at researcher support centre, school of Nursing. North Carolina: Chapel Hill.

Zikmund, G. W. (2000). Business research methods (7th ed.).

Zirger, B., \& Maidique, M. (1990). A model of new-product development: An empirical test. Management Science, 36(3), 867-883. http://dx.doi.org/10.1287/mnsc.36.7.867

\section{Copyrights}

Copyright for this article is retained by the author(s), with first publication rights granted to the journal.

This is an open-access article distributed under the terms and conditions of the Creative Commons Attribution license (http://creativecommons.org/licenses/by/3.0/). 